\title{
The three phases of the energy transformation - combining governance and business model innovation
}

This chapter merges the findings of the two preceding chapters - on the importance of governance and the simultaneous development of business models - in moving from the conventional, fossil fuel-based energy system to one that is decentralised, renewable and based on energy efficiency. It highlights characteristics of three distinct phases during that transition and concludes that it is vital to align governance (policies, network rules, market rules, institutions etc.) with flexible system operation to achieve a smooth transition. In the context of developing countries with incomplete grid infrastructure, regulatory incentives and business initiatives may lead to a leapfrogging effect from Phase I to Phase III, though.

\subsection{Three phases of the transformation}

The transformation towards a decentralised energy system entails both regulatory incentives as well as entrepreneurial initiatives. There are three broad phases in moving from the conventional, fossil fuel-based energy system to one that is decentralised, renewable and based on energy efficiency.

In technical terms, Phase I can roughly be associated with a niche deployment of decentralised renewable energies; in Phase II, their contribution rises to become a major player in the supply portfolio, enabled by governance which provides value for the necessary system flexibility requirements; and Phase III is characterised by decentralised renewable energies as the dominant player within a flexibly operated system.

The following table describes the main features of each phase.

How to cite this book chapter:

Burger, C., Froggatt, A., Mitchell, C. and Weinmann, J. 2020. Decentralised Energy a Global Game Changer. Pp. 261-275. London: Ubiquity Press. DOI: https://doi. org/10.5334/bcf.t. License: CC-BY 4.0 
Table 5: Overview of the three phases of energy transformation.

\begin{tabular}{|c|c|c|c|}
\hline & Phase I & Phase II & Phase III \\
\hline & $\begin{array}{l}\text { Grid-based and } \\
\text { centralised system } \\
\text { with decentralised } \\
\text { renewables as a } \\
\text { niche phenomenon } \\
\text { (contribution to total } \\
\text { power generation less } \\
\text { than } 10 \text { per cent) }\end{array}$ & $\begin{array}{l}\text { Decentralised } \\
\text { renewables growing } \\
\text { in importance } \\
\text { (contribution to total } \\
\text { power generation up } \\
\text { to } 40 \text { per cent) }\end{array}$ & $\begin{array}{l}\text { Decentralised } \\
\text { renewables as } \\
\text { dominant player with } \\
\text { fully autonomous } \\
\text { solutions not } \\
\text { connected to a } \\
\text { central grid }\end{array}$ \\
\hline Governance & $\begin{array}{l}\text { Centralised system } \\
\text { regulation } \\
\text { - Promoting } \\
\text { renewables } \\
\text { - Promoting local } \\
\text { and national } \\
\text { industry } \\
\text { - Promoting lead } \\
\text { markets }\end{array}$ & $\begin{array}{l}\text { Performance based } \\
\text { regulation } \\
\text { - Evaluating } \\
\text { decentralised } \\
\text { renewable } \\
\text { generation versus } \\
\text { network costs } \\
\text { - Flexibility and } \\
\text { energy efficiency } \\
\text { incentives } \\
\text { - Integrating } \\
\text { customers } \\
\text { - Integrating } \\
\text { electricity, heat } \\
\text { and mobility } \\
\text { (convergence) }\end{array}$ & $\begin{array}{l}\text { Consumer focused } \\
\text { ambition driven } \\
\text { regulation } \\
\text { - Users can } \\
\text { choose the level } \\
\text { and method of } \\
\text { security of their } \\
\text { supply } \\
\text { - Co-existence } \\
\text { of central and } \\
\text { decentralised } \\
\text { systems and } \\
\text { regulations }\end{array}$ \\
\hline \multirow{3}{*}{$\begin{array}{l}\text { Business } \\
\text { models }\end{array}$} & \multicolumn{3}{|c|}{ - New asset ownership models: from central to crowdfunding } \\
\hline & \multicolumn{3}{|c|}{$\begin{array}{l}\text { - New service and operating models: from bundled to autonomous } \\
\text { operations }\end{array}$} \\
\hline & \multicolumn{3}{|c|}{ - New platform models: from aggregators to open platforms } \\
\hline $\begin{array}{l}\text { Core } \\
\text { competencies }\end{array}$ & $\begin{array}{l}\text { - Financing and } \\
\text { enabling asset } \\
\text { ownership } \\
\text { - Technology leads } \\
\text { and product } \\
\text { innovation }\end{array}$ & $\begin{array}{l}\text { - Customer } \\
\text { centricity and } \\
\text { meaningful } \\
\text { consent } \\
\text { - Partnerships and } \\
\text { bundled services } \\
\text { - Technology leads } \\
\text { and product } \\
\text { innovation }\end{array}$ & $\begin{array}{l}\text { - Financing and } \\
\text { enabling asset } \\
\text { ownership (ICO) } \\
\text { - Technology leads } \\
\text { and product } \\
\text { innovation } \\
\text { - Platforms and } \\
\text { ecosystems }\end{array}$ \\
\hline Risks & - Low risk & $\begin{array}{l}\text { - Risk of stranded } \\
\text { investments in } \\
\text { fossil/nuclear } \\
\text { assets }\end{array}$ & $\begin{array}{l}\text { - Risk of stranded } \\
\text { investments in } \\
\text { transmission grids }\end{array}$ \\
\hline
\end{tabular}

Source: Authors' contribution. 


\subsection{Phase I (Energiewende 1.0): grid-based and connected energy system with decentralised renewables as a niche $(<10$ per cent $)$}

\subsubsection{Governance of Phase I: centralised system regulation promoting renewables, local industry, and lead markets}

Most countries in the world have ratified targets for the rollout of renewable energies (Ren21 2017a). The encompassing objective typically is the move towards less carbon-intensive energy supply, thus contributing to the reduction of greenhouse gases.

Governance in Phase I is driven by incentivising the deployment of renewables. In some countries, the introduction of regulatory incentives to promote renewable energies was accompanied by objectives related to industrial policy, in the attempt to create lead markets for solar cell manufacturers or wind turbine producers. For example, the Danish wind turbine industry and the German photovoltaic manufacturers greatly benefitted from direct and indirect subsidies and support schemes governments imposed to promote these technologies (Lipp 2007; Nicolini \& Tavoni 2017; Strunz, Gawel \& Lehmann 2016).

Some of these joint renewable and industrial policies were successful, for example the development of Danish wind turbine producer Vestas on the back of policies to support domestic wind energy. Vestas is still among the world's leading wind turbine manufacturers, providing a role model of where public and corporate interests have been aligned.

Other incentives such as those for solar photovoltaics in Germany led to short boom for some German photovoltaic manufacturers. In the longer term, those manufacturers, for example SolarWorld (DW 2017), could not compete with companies from countries with much lower unit production costs, in particular China. The ambition of the German government to create an East German 'Solar Valley' in the state of Brandenburg did not yield the expected results. Most of the companies either went into bankruptcy when the incentives were reduced, or were acquired by Asian competitors (Fuchs 2015). However, it has also led to the development of 'second' generation photovoltaic knowledge in Germany, as well as the development of inverters and fittings - which make up 40 per cent of the cost of the panels (Wirth 2018). In the longer term, higher shipping costs and long delivery times may improve the competitiveness of German and European manufacturers vis-à-vis their Asian competitors (ibid.).

Other countries, such as the Netherlands, decided to follow a wait-and-see strategy and initiated incentive schemes only after the costs per kilowatt hour were substantially reduced.

The advantage of that strategy is that it avoided any boom-and-bust of Dutch manufacturing industries and saved direct subsidies, that is, Dutch taxpayers' money. The benefits have to be counterbalanced, though, with potentially 
negative consequences for countries like the Netherlands in terms of innovation capabilities, because of the limited involvement and experience with new energy technologies and system operation.

In Phase I, energy governance encompasses direct policies primarily in support of new capacity, but also other issues related to network access rules, market rules and design, retail competition rules, and so on. The most common policy incentives in support of renewable energy development are feed-in tariffs (FITs), net metering, and renewable portfolio standards. All instruments have their pros and cons (SSREN 2012):

- Feed-in tariffs (FITs) are based on a fixed remuneration per kilowatt hour fed into the grid, typically over a time horizon of ten to twenty years, and can be considered a long-term purchase agreement. FITs typically guarantee a fixed price per $\mathrm{kWh}$, an offtake contract, and priority access to the network and electricity market. This means that risk is substantially reduced for investors, and it is possible to borrow money on the contract. There are multiple examples of FITs in different countries, including Australia, China, Denmark, and the United States, with Germany generally seen as the most successful case - see country Section 2.9.

FITs tend to be technology specific, which means the remuneration given depends on the technology and its investment costs. With this instrument, governments can steer their support towards individual renewable sources which would not be competitive in market-based approaches, for examples auctions. Historically, solar power has benefitted from FITs.

In Phase I of the energy transformation, feed-in tariffs provide market certainty for investors (Cox \& Esterly 2016), but they may become too expensive in later stages and be replaced by more market-based instruments: 'Policymakers have recently been moving towards designing FITs as a premium in addition to the current market rate for electricity, known as feed-in premiums' (ibid.).

- Another Phase I type policy in support of scaling technologies is Net Energy Metering (NEM), also called Net Metering. It allows residential owners of photovoltaic panels to sell their surplus electricity to the local utility at retail rates - the meter in effect turns back for every kWh that is injected from home into the grid. In return, households benefit from a net reduction of their utility expenses. NEM originates from the United States, and has been a popular instrument there. As of November 2017, 38 US states, Washington DC, and four territories offer net metering incentives (NCSL 2017). Especially in states in the south-western part of the United States with high solar radiation or in states with high electricity tariffs, such as in the New England states in the north-eastern part of the country, net metering can significantly lower the electricity bill of prosumers.

- The third major instrument in Phase I are Renewable Portfolio Standards (RPS), also called Renewable Energy Standards - again, usually found 
in the United States, and often in conjunction with net energy metering. Renewable Portfolio Standards force utilities to reach a certain percentage of renewable energies in their portfolio within a given time frame. Depending on their design - for example, through tendering or auctions - they are often intended to encourage competition between external providers as well as between technologies to achieve the maximum reduction of greenhouse gas emissions at the lowest price.

When choosing policy incentives, policy makers have to consider their effect on promoting centralised or decentralised generation infrastructure, illustrated in Figure 40. The set-up of the instruments may have a fundamental impact on the infrastructure. With quotas, capacity payments, or renewable portfolio standards investor-owned utilities (IOUs) tend to build central infrastructure in line with their current business model and core competencies, whereas FITs, Net Metering, or Demand-Side Response (DSP) tend to attract decentralised infrastructure enabling a faster transformation towards Phase III.

During this first phase of development, the system is dominated by incumbent generators and suppliers, and grid operations remain centrally controlled by transmission and distribution system operators, as they have been for previous decades. The total contribution of power generation from new renewables hovers below critical thresholds. There is very limited impact on system operation, system costs, average electricity costs or on displacement of fossil fuels and nuclear power in the merit order. Utilities, system operators, and private companies are able to use the first experiences of intermittent sources within electricity systems to learn to develop and apply forecasting models and develop processes for information exchange, billing and accounting, and potential operational issues (Baumgartner 2017).

However, although the actual percentage of decentralised renewable electricity may not be high, it is also possible for countries to find the ownership of their generation transformed during this first phase - as with Denmark in the 1980s and 1990s (see also Section 2.8).

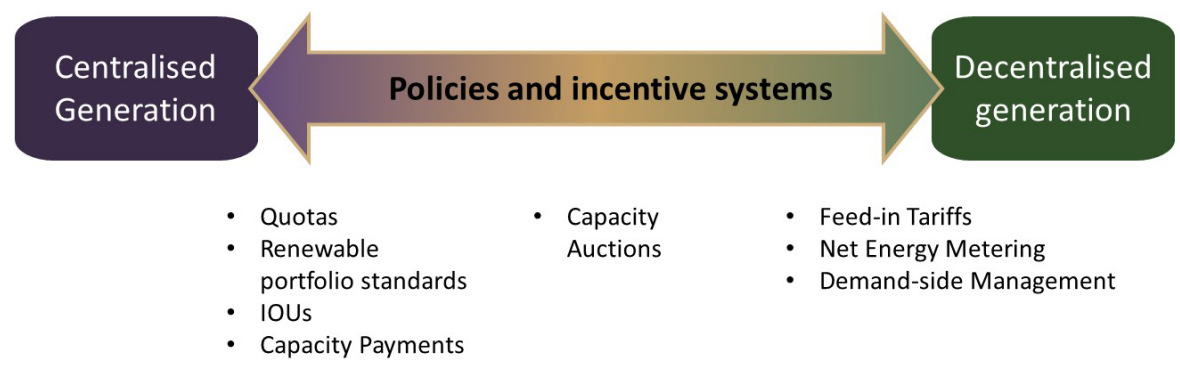

Figure 41: Policy incentives in centralised and decentralised systems.

Source: Authors' contribution. 


\subsubsection{Business models and core competencies of Phase I}

In Phase I of the energy transformation, the traditional business model of power companies remains relatively unaffected by the deployment of renewables as their contribution remains low. Incumbent utilities continue to supply the vast majority of power, balancing against largely predictable demand fluctuations. The main investment uncertainties are about future demand and the price of fossil fuels.

Business models evolve around new offers in terms of financing, installation and operations of decentralised renewable energy assets. Private investors are attracted to participate in the energy market because of the low-risk purchase guarantees, available through instruments such as feed-in tariffs or net metering. Bioenergy villages and energy associations are founded, which rely on participatory decision-making and financial contributions from their members.

In this phase, it is not the volume of renewable energies that is transformative. For institutional investors, one of the most appealing attributes of renewables is that they are scalable. Cost reductions of renewable technologies have made even smaller-scale deployment economic, enabling small and medium-sized companies to enter into a market previously dominated by vertically integrated utilities, and small domestic or commercial level consumers to become prosumers. Consequently, decentralised generation, combined with energy efficiency and balancing of localised markets, creates the knowledge and human resource foundation for a broader decentralised supply industry.

Start-ups, utilities, and new entrants from other sectors, in particular information and communication technologies (ICT) and finance, gather expertise from the experience with first installations and pilot projects. In the first pioneering countries and states of the energy transformation, such as California, Denmark, and Germany, innovation has mainly focused on technologies and products, in particular the decline of unit costs of technologies such as solar cells and wind turbines, whereas in countries that have started later with programs to promote decentralised renewables, the momentum shifts from product to service innovation - with sophisticated financing models, integrated solutions such as smart homes, and a digital ecosystem.

\subsection{Phase II (Energiewende 2.0): decentralised renewables growing in importance with partially autonomous solutions}

\subsubsection{Governance of Phase II: setting the ground for Energiewende 3.0 with performance-based regulation}

When the system moves into Phase II, policy makers start modifying incentive systems, as the costs of renewable technologies fall and their deployment becomes more widespread. Simultaneously, government and regulators develop 
a deeper understanding of the key decisions they have to make if they want cost-effective, higher percentages of renewables (REN21 2017b). The earlymover countries are observed to abandon the initial subsidy schemes and establish more market-based mechanisms, such as auctioning, in parallel to FITs for smaller scale technologies. However, late-adopter countries are able to benefit from the impact of the first movers.

In this phase, the challenge for managing the governance framework is to ensure stable market conditions while creating a regulatory environment that encourages innovation and new market actors. The governance framework sets the policy direction and creates the regulatory framework to implement instruments that support and incentivise new actors or penalise uncompetitive practices, either via top-down or bottom-up processes.

In Phase II, governance has to lay the foundations for flexibility and energy efficiency, integrating consumers, developing mechanisms to deliver meaningful consent from people and society for the transformation, as well as electricity with heat and transport, and to evaluate network costs versus decentralised solutions. All these elements become crucial for a smooth transition to and as part of Phase III, where differing proportions of central to decentralised systems co-exist. Management of the process and expectations of the stakeholders involved becomes an important part to enable adaptation to new circumstances. Participatory approaches to integrate customers' requests and wishes into the public discourse are established, for example with regards to a higher density of wind turbines next to residential neighbourhoods, or the construction of new transmission lines (or the reinforcement of existing lines).

As the percentage of variable renewables increase, and if the system is operated in the same way as during Phase I, security of supply shifts to the attention of regulators and policy makers. The transmission and distribution grids have to be reinforced and expanded in certain areas. The distribution grid is affected, because conventional lines were laid out to unidirectionally satisfy residential demand. If entire neighbourhoods or even villages start producing their photovoltaic energy with decentralised units - and no adequate local storage solutions can temporarily absorb the power - supply may exceed local demand, and the electricity has to be transported to the next load centre. Large-scale wind power makes additional investments necessary at higher-voltage transmission levels, because - similar to photovoltaics in rural areas - wind power tends not to be produced in areas with high demand, such as urban agglomerations and their adjacent industrial sites.

Thus, increasing amounts of renewables requires new ways of regulation and operation of the system so that expensive additional transmission and distribution capacity can be kept to a minimum. The type of regulation and compensation mechanisms has a fundamental impact on how much additional transmission and distribution infrastructure capacity is required and the number of interventions needed by the grid operators, and this of course also affects the final cost of electricity to the customer (Shakoor, Davies \& Strbac 2017). 
As outlined in Section 2.9.4, the move to more flexible system operations is likely to reduce costs and ensure security of supply. It is not only a key requirement for Phase II but also the enabler of Phase III of the energy transformation. If the system becomes flexible very fast, Phase II may be substantially shortened and the transformation can occur in a non-disruptive way. Ensuring sufficient flexible resources and coordinating them efficiently is therefore a central aspect of the transformation from a fossil-based electricity system to a decentralised one.

Flexibility measures can include, for example, building short-term storage facilities, such as stationary batteries, improving industrial and residential demand-side response, reducing short-term and long-term energy consumption, and implementing local markets. Flexibility is closely linked to energy efficiency. Incentives to increase energy efficiency include both measures directed towards end users to enhance the efficiency of their buildings and appliances, as well as incentives to increase efficiency of energy system operations. The coordination of heat, electric mobility and decentralised power generation offers new possibilities to adapt demand to inelastic supply by intermittent renewables.

The least expensive solution to increased flexibility and efficiency during Phase II is demand-side response, though. As a platform model, it builds on the existing assets, exploits their flexibility potential, and brings down peak infrastructure needs and peak costs. The interview with Oliver Stahl, founder of German demand-response pioneer Entelios, in Section 3.5 of this book provides insights into the underlying mechanisms and business models.

Each of the policy interventions of Phase II will of course have to be counterbalanced with questions of privacy and data protection (see also Burger, Trbovich \& Weinmann 2018). Until now, society has collectively embraced the transfer of private information as a compensation for services it gets for free by providers such as Facebook, Google, What's App, or Amazon. Sociologists call this willingness to share certain aspects of one's life the 'Privacy Paradox' (Wittes \& Liu 2015; van Zoonen 2016; Wittes \& Kohse 2017). Understanding what this means for society, and hence energy, is still in its infancy.

While there is a logical progression from Phase I to Phase III, how long any country needs to stay in Phase II is not pre-determined, and may in future be shortening as new technologies become economically viable and widely available. As Chapter 2 has shown, a key determining factor will be the governance framework and the efficiency of its coordination that can accelerate or slow down the rate of new technology deployment.

\subsubsection{Business models and core competencies of Phase II}

In Phase II of the energy transformation, the deployment of decentralised renewables becomes non-negligible and increasingly affects system and market operations. 
The larger intake of renewable sources typically reduces wholesale market prices. On the European Energy Exchange, the spot-market power price fell to $€ 29$ per Megawatt hour in 2016, down from more than $€ 70$ per Megawatt hour in 2008. This trend is caused by the low operating costs of renewables, which crowd out more expensive coal and gas-fired thermal plants on the dispatch curve in the conventional marginal cost electricity market design (Thalman 2015).

In the short term, low wholesale prices are beneficial for consumers. If prices fall below certain thresholds of viable commercial operations, though, utilities may start mothballing or even dismantling central power plants. From a public perspective some of this may have positive effects - for example, the closure of coal plants to curb greenhouse gas emissions. However, flexible natural gas plants may compensate for supply fluctuations in the move towards systems with a higher share of decentralised renewable energies. In this situation, closure of flexible gas plants may not be in the mid-term public interest. Consequently, policy makers may modify the regulatory framework by setting up capacity markets for targeted flexible generation. In addition, they have to establish appropriate compensation mechanisms for stranded nuclear or fossil assets of utilities.

For conventional electric utilities, Phase II of the energy transformation leads to fundamental changes in their business model. Declining revenues from wholesale markets and thermal plants turning into stranded assets leads to financial stress. The orientation towards customer centricity and mind shift from large scale to small scale, in particular individualised energy efficiency solutions, cannot be expected to occur over night. Moreover, utilities have to deal with dwindling market shares in the new system, as new entrants threaten their positions. Digitalisation and falling technology prices enable players from other sectors and even start-ups to step in and establish themselves offering integrated solutions in the utilities' core markets. Utilities become aware that they cannot compete with tech giants and ICT firms on their own - hence, they start entering partnerships and alliances with telecommunication companies, providers of smart goods or start-ups to provide complex service solutions, for example in the smart home or electric vehicle charging markets. Product innovation then becomes a joint effort, connecting the digital ecosystem with smart devices.

As already highlighted, the introduction of feed-in-tariffs, especially for solar and wind, has enabled individuals, energy associations and local communities to invest in renewable energy. This is now expanding with consumers showing active engagement in combined storage and solar systems. New business models are enabling installations without, or with less, government support. In Germany and Australia, individual households with batteries and solar PV are being offered free electricity when they are unable to generate their own supply, in return for their batteries being used to maintain grid frequency - the creation of virtual power plants (Energy Brainpool 2016; Griffith 2017). 
Increasing automation and data processing capabilities are leading to the development of new apps and platforms. A wide range of companies emerges, which automatically aggregate consumers buying power (such a Labrador power in the United Kingdom) and develop opportunities for flexible demand (such as Tempus Energy in Australia). These companies require consent from consumers to enable them to facilitate the automatic switch between suppliers and to vary consumption. The success of these companies is determined both by the regulatory environment in which they operate, and the on-going trust of consumers. Data management and automation is likely to reduce the need for active engagement of consumers to reduce their energy consumption; however, it will not eradicate it. If there is a societal consensus to curb greenhouse gas emissions, conscious lifestyle changes and consumer behaviour shifts are also needed.

The major change in business models during Phase II is the focus on customers' needs. Energy is no longer a commodity to be sold via the meter, it rather becomes a unique combination of technologies adapted to each individual rooftop (with respect to PV installations), to the topography of the territory (with respect to wind turbines), or to the agricultural intake from local farmers for biomass co-generation technologies. Decentralised deployment of renewable energy technologies supports local businesses and technicians, thereby creating local value.

\subsection{Phase III (Energiewende 3.0): decentralised renewables as dominant player with fully autonomous solutions}

\subsubsection{Governance of Phase III: consumer- focused, ambition-driven regulation}

The third phase of the energy transformation, or 'Energiewende 3.0', is characterised by decentralised renewable energies becoming the major player in the supply structure. Phase III is yet to exist in any developed country. Some countries and regions, such as Australia, Denmark, Germany, Ireland, as well as some states in the United States, experience prolonged intervals in electricity supply when new renewable energies account for the main source of primary electricity. For example, in March 2018 Portugal's renewable energy production exceeded power demand and accounted for more than 100 per cent of mainland electricity consumption (Reuters 2018). However, so far, even countries with higher proportions of decentralised renewable generation have not moved to becoming highly flexible energy systems. This flexibility characteristic can be seen as a key determinator of moving from Phase II to Phase III. Governance - meaning market design, network rules and incentives, tariff policy, its coordination and so forth - has been changed by the time a country becomes a Phase III country. 
In rural settings of countries in the developing world, such as India, key characteristics of Phase III already exist, albeit often on a very low level of the energy ladder, and with substantial financial disadvantages for local residents.

The transformation is likely to occur in most geographic contexts, but its dynamics may vary across countries and continents. Different phases might co-exist across regions of a single country, for example in urban versus rural settings. Some countries might opt for largely remaining within the Phase I configuration, for example, if energy generation is predominantly based on large, central hydropower dams, which often produce cheap and climateneutral electricity. Especially in developing countries with low electrification ratios, companies and governments may be able to leverage lessons learned in a Phase I environment and leapfrog directly to Phase III with largely autonomous island systems.

In the first two phases of the energy transformation, the pace of deployment of renewables is to a large extent determined by the national governance framework, including the ability of local administrations to be involved.

As electrification occurs in new sectors, such as transport, and to improve the efficiency of electricity generation, the governance framework needs to enable the co-existence of different systems: central grid-based, autonomous decentral entities and regions, further integration of heat and e-mobility. As the energy system decentralises, the importance of a distribution level system coordinator increases, to not only manage technical operations in the interest of all stakeholders, but also to stimulate new markets and thus enable new entrants and innovators. The increasing coordination function of the distribution system operator, leads to their development as a platform provider or Distribution System Platform.

At the heart of the future system must be performance-based regulation, which not only ensures supply obligations to be met, but also wider social and environmental sector goals to be delivered. This means that reforming regulation will encompass how to deal with winners and losers - and this is more than creating an open and transparent decision-making process. Society as a whole has to enter a public discourse over price stability and security of supply, jobs and corporate interests, climate change and effects on the local environment, for example wind turbines or large PV fields, and how to deal with stranded assets, in particular obsolete long-haul transmission lines.

Regulatory instruments, such as the introduction of capacity payments discussed in Phase II, can give rise to supply stability, but may also, in some cases, support incumbents' fossil-fired power plants that were scheduled to be mothballed because of environmental reasons. With intermittent solar and wind intake, there will be a resource abundance at certain times, and extreme scarcity (and high prices) at other times. Hence, storage will become a major issue for policy makers.

The need to rapidly decarbonise the economy may impose targets and objectives that require the deployment of low-carbon technologies even at a faster 
rate than the market would ordinarily deliver. This may lead to additional policy-driven market interventions. Under the right regulatory environment, the next wave of technologies could be rapidly deployed at scale, as they have uses beyond the traditional power sector. While the development of batteries is being driven by and for electric vehicles, it will have important implications for both grid level and individual electricity storage.

The balance between public and private ownership and engagement within the power sector varies between countries. However, in general the most rapid move towards Phase III will occur within systems which encourage innovation and entrepreneurship, and this is likely to be delivered by the private sector, providing the market is fair and transparent and constructed to value the characteristics of renewable energies and demand-side response, and appropriate governance mechanisms are in place.

\subsubsection{Business and core competencies of Phase III}

In Phase III, private platforms, autonomous residents, and local grid ecosystems will co-exist with the central grid, leading to an increasing diversity of business models that range from convenient standard packages for energy services with flat rates, similar to insurances, to fully customised solutions for self-producing individuals or communities. Multinational companies, such as Google, Amazon, or Apple, will co-exist with start-ups and local initiatives.

The electricity supply industry will be forced to leave its roots as public infrastructure service and transform into truly private businesses, offering customised solutions for each consumer, while independent system operators or private transaction platforms take over responsibilities of grid control.

Digitalisation will of course be a main driver for innovation. It will cope with the complexities of the energy grid using sensors, smart meters, drones, and augmented/virtual reality in fields as diverse as predictive maintenance, customer care, and weather forecasts. Companies that embrace Artificial Intelligence and Neural Networks to detect patterns in their data will have a latent advantage over companies that solely rely on conventional computational methods. However, energy supply will always entail a technical, engineering component. Manufacturers of their own technological devices may have a competitive advantage vis-à-vis data-only companies.

Private platforms and ecosystems with micro-trading and coordination of local balancing markets will emerge. Australian start-up Power Ledger has issued the first Initial Coin Offering in the Australian energy sector and builds a blockchain-based application platform to facilitate peer-to-peer trading, monitoring of flows in the transmission grid, and plans to implement many other transaction-related functionalities.

Globalisation will allow for dispersed business operations. For example, start-ups Mobisol and SOLshare have established remote operating centres in 
Berlin, from which they track and monitor the performance of their installations in sub-Saharan Africa and South Asia. Services offered in remote, rural areas integrate energy in a holistic package of services, as in the case of Solarkiosk. Energy companies and start-ups team up with players such as Total or Coca-Cola to correspond to customer needs.

In the past, trickle-down effects of innovations typically happened from industrialised to developing countries, but in Phase III new business models and digital technologies may first emerge in the developing world and then find their way to the industrialised nations. Born out of the need to experiment with autonomous micro-grids, with integrated rooftop systems, and with payment and financing methods based on the Blockchain, start-ups and entrepreneurs in developing countries may establish decentralised energy ecosystems that complement or even substitute the central grid.

This stage of transformation creates increased risks of stranded assets for existing technologies and their operators. Without transitional assistance, incumbents may delay the sector transformation. While governance bodies often focus on Phase I objectives and on how to adapt regulation, they may neglect the impact of these policies on future infrastructure.

Thinking from Phase III backwards may be an alternative approach in corporate and political decision making, allowing for a more rigorous strategy and adaptation.

\subsection{References}

Baumgartner, D. (2017), How to integrate a high share of renewables into the grid? HEC-ESMT Energy Course. C. Burger and J. Weinmann. Berlin, Elia Grid International.

Burger, C., Trbovich, A. \& Weinmann, J. (2018), Vulnerabilities in smart meter infrastructure - can blockchain provide a solution? Results from a panel discussion at EventHorizon 2017, Background Paper, German Energy Agency DENA/ESMT. Retrieved from https://press.esmt.org/all-pressreleases/blockchain-can-improve-data-security-energy-infrastructure

Cox, S. \& Esterly, S. (2016), Renewable electricity standards: good practices and design considerations. Technical Report NREL/TP-6A20-65503. Golden, CO: NREL (National Renewable Energy Laboratory)

DW. (2017), Solarworld to file for insolvency, 10 May 2017. Retrieved February 15, 2019, from https://www.dw.com/en/germanys-solarworld-files-forbankruptcy-again/a-43166235

Energy Brainpool. (2016), First free-of-charge electricity flat rate in Germany, 22 September 2016. Retrieved February 15, 2019, from https://blog.energy brainpool.com/en/first-free-of-charge-electricity-flat-rate-in-germany/

Fuchs, R. (2015). Auf der Suche nach einem Neuanfang. Länderreport, Deutschlandfunk Kultur. Retrieved February 15, 2019, from https://www. 
deutschlandfunkkultur.de/solar-valley-in-der-region-bitterfeld-auf-dersuche-nach.1001.de.html?dram:article_id=336366

Griffith, C. (2017, July 6), Germany's sonnen offers 'free' grid power deal to solar users, The Australian. Retrieved February 15, 2019, from https://www. theaustralian.com.au/business/technology/germanys-sonnen-offers-freegrid-power-deal-to-solar-users/news-story/9b8f9fd7af1279f9dd49f6d226b c7a34

Lipp, J. (2007), Lessons for effective renewable electricity policy from Denmark, Germany and the United Kingdom. Energy Policy 35(11), 5481-5495.

NCSL. (2017), State net metering policies. Retrieved December 17, 2017, from http://www.ncsl.org/research/energy/net-metering-policy-overview-andstate-legislative-updates.aspx

Nicolini, M. \& Tavoni, M. (2017), Are renewable energy subsidies effective? Evidence from Europe. Renewable and Sustainable Energy Reviews, 74,, 412-423.

Ren21. (2017a), Renewables 2017, global status report, renewable energy policy network for the 21st century. Retrieved from http://www.ren21.net/wpcontent/uploads/2017/06/17-8399_GSR_2017_Full_Report_0621_Opt.pdf

Ren21. (2017b), Renewables global futures report: great debates towards 100 percent renewable energy, 2017. Retrieved from http://www.ren21.net/wpcontent/uploads/2017/10/GFR-Full-Report-2017_webversion_3.pdf

Reuters. (2018), Portugal looks to renewables as March output tops mainland power demand. Retrieved February 15, 2019, from https://www.reuters. com/article/portugal-energy-renewables/portugal-looks-to-renewablesas-march-output-tops-mainland-power-demand-idUSL5N1RG35T

Shakoor, A., Davies, G. \& Strbac, G. (2017), Roadmap for flexibility services to 2030, Pyory, published by The Committee on Climate Change, May 2017. Retrieved February 15, 2019, from https://www.theccc.org.uk/wp-content/ uploads/2017/06/Roadmap-for-flexibility-services-to-2030-Poyry-andImperial-College-London.pdf

SRREN. (2012), Special report on renewable energy sources and climate change mitigation, Special Report of the International Panel on Climate Change. Intergovernmental Panel on Climate Change, Working Group III - Mitigation of Climate Change. Cambridge, UK: Cambridge University Press.

Strunz, S., Gawel, E. \& Lehmann, P. (2016), The political economy of renewable energy policies in Germany and the EU. Utilities Policy, 42(C), 33-41.

Thalman, E. (2015, August 6), Energiewende effects on power prices, costs and industry German industry and its competitive edge in times of the Energiewende. Clean Energy Wire. Retrieved February 15, 2019, from https:// www.cleanenergywire.org/dossiers/energiewende-effects-power-pricescosts-and-industry

van Zoonen, L. (2016), Privacy concerns in smart cities. Government Information Quarterly, 33(3), 472-480. 
Wirth, H. (2018), Recent facts about photovoltaics in Germany, Fraunhofer Institute, February 2018. Retrieved February 15, 2019, from https://www. ise.fraunhofer.de/content/dam/ise/en/documents/publications/studies/ recent-facts-about-photovoltaics-in-germany.pdf

Wittes, B. \& Kohse, E. (2017), The privacy paradox II: measuring the privacy benefits of privacy threats. Retrieved February 15, 2019, from https://www. brookings.edu/wp-content/uploads/2017/01/privacy-paper.pdf

Wittes, B. \& Liu, J.-C. (2015), The privacy paradox: the privacy benefits of privacy threats. Retrieved February 15, 2019, from https://www.brookings. edu/wp-content/uploads/2016/06/Wittes-and-Liu_Privacy-paradox_v10. pdf 
